\title{
The Glycolysis Puzzle: From Glucose to Pyruvate and Everything in Between
}

\author{
Alma Rodriguez Estrada
}

\author{
Aurora University, Biology Department, 347 S Gladstone Ave, Aurora Illinois 60506 USA \\ (arodriguezestrada@aurora.edu)
}

\begin{abstract}
Glycolysis is the first stage of cellular respiration where glucose is broken down to pyruvate (pyruvic acid). Glycolysis involves a total of 10 steps through which glucose is split and partially oxidized to pyruvate. The 10 steps of glycolysis might be difficult to understand and remember. However, knowing details about this pathway is essential to learn the later stages of aerobic cellular respiration, fermentation and gluconeogenesis. Furthermore, a solid knowledge of glycolysis is essential to understand the regulatory mechanisms of glycolysis and how other sugars and intermediates can enter and leave the pathway. The glycolysis puzzle activity involves group work where the participants are provided with structures, names of enzymes, free energy change values and a worksheet that briefly describes each step of glycolysis. The task is to assemble the glycolytic pathway, discuss the rationale behind each chemical reaction, explore the key regulatory steps and allosteric enzyme effectors, among others.
\end{abstract}

Keywords: Glycolysis, metabolism, pathway, cellular respiration, pyruvate

\section{Introduction}

Glycolysis is the first stage of cellular respiration where glucose is split and partially oxidized to pyruvate. Glycolysis is composed of 10 enzyme-catalyzed reactions and it can be divided in two phases: preparatory and payoff phases. During the preparatory phase (five steps), two molecules of ATP are invested and the sugar is split to glyceraldehyde-3-phosphate (GAP). During the payoff phase (five steps), GAP is converted to pyruvate and energy is conserved in the form of ATP (substrate-level phosphorylation) and NADH (Nelson and Cox 2013, Voet et al. 2016).

Learning the steps of glycolysis can be a daunting and dull yet essential task in advanced courses such as biochemistry (Songer and Mintzes, 1994). The glycolysis puzzle is an active learning and paper-based activity where students work in groups assembling the glycolytic pathway. Students are handed an envelope that contains all the intermediates of glycolysis, the names of all enzymes involved, a large easel sheet and a worksheet that partially describes the pathway. With minimal help from the instructor, participants assemble the pathway and answer the associated questions.

The glycolysis puzzle has been used in an upperlevel, one-semester biochemistry course taken by third and fourth-year biology and health science majors. In this course, metabolism is covered during the last quarter of the semester and the participants have acquired background knowledge related to thermodynamics, enzymology and an introduction to metabolism.

The glycolysis puzzle allows students to reason out the chemical reactions of glycolysis and to think about the rationale behind them, rather than just memorizing the individual steps. Also, this group activity encourages peer learning as students teach one another. 


\section{Student Outline \\ The Glycolysis Puzzle}

\section{Objectives}

- Explain the function and relevance of the glycolytic pathway.

- Recall and explain the rationale of all chemical reactions involved in the glycolytic pathway.

- Determine key regulatory steps of glycolysis.

\section{Introduction}

Glycolysis is the first stage of cellular respiration where glucose is broken down to pyruvate. Glycolysis involves a total of 10 steps through which glucose is split and partially oxidized to pyruvate. Glycolysis can be divided in two phases: preparatory and payoff. During the preparatory phase, ATP is invested and the sugar is split into two, three-carbon molecules. During the payoff phase, the three-carbon molecules are converted to pyruvate and energy is conserved in the form of ATP and NADH (Nelson and Cox 2013, Voet et al. 2016).

This activity involves group work. Here, you are provided with structures, names of enzymes and a worksheet that briefly describes each step of glycolysis. Your task is to assemble the glycolytic pathway, discuss the rationale behind each chemical reaction, explore the key regulatory steps and allosteric enzyme effectors, among others.

\section{Materials}

- Worksheets (one per student)

- A large 25" x 30 " easel sheet

- Envelope with structures and enzymes

- $\quad$ Sticky notes

- $\quad$ Adhesive tape

- $\quad$ Thin markers

\section{Instructions}

1. Remove the structures and enzymes from the envelope. At this point, you might want to separate sixcarbon and three-carbon molecules.

2. Table 1 specifies the names and descriptions of the intermediates of the glycolytic pathway. Match the descriptions with the structures and label them. Use the sticky notes to write the names and stick the note over the white rectangle underneath each structure. 
Table 1. Metabolic intermediates of the glycolytic pathway (not in order of formation).

\begin{tabular}{|c|c|}
\hline Molecule & Description \\
\hline 1,3-bisphosphoglycerate (1,3-BPG) & Phosphorylated aldotriose at carbons 1 and 3 \\
\hline Glyceraldehyde-3-phosphate (GAP) & Phosphorylated aldotriose at carbon 3 \\
\hline Glucose & Six-carbon aldose sugar \\
\hline Pyruvate & $\begin{array}{l}\text { Three-carbon molecule with a carboxylic acid and a ketone functional group. } \\
\text { Deprotonated form of pyruvic acid. }\end{array}$ \\
\hline Fructose-1,6-bisphosphate (FBP) & Six-carbon ketose phosphorylated at the hydroxyl group on carbon 1 and 6 . \\
\hline 2-phosphoglycerate (2PG) & $\begin{array}{l}\text { Deprotonated form of the monophosphoglyceric acid ( } 3 \text { carbon molecule) } \\
\text { having the phospho group at the 2-position. }\end{array}$ \\
\hline 3-Phosphoglycerate (3PG) & $\begin{array}{l}\text { Deprotonated form of the monophosphoglyceric acid ( } 3 \text { carbon molecule) } \\
\text { having the phospho group at the } 3 \text {-position. }\end{array}$ \\
\hline $\begin{array}{l}\text { Dihydroxyacetone phosphate } \\
\text { (DHAP) }\end{array}$ & A phosphorylated (C3) ketotriose \\
\hline Glucose-6-phosphate (G6P) & Phosphorylated glucose at the hydroxyl group on carbon 6 \\
\hline Phosphoenolpyruvate (PEP) & Three-carbon anion. Ester derived from the enol of pyruvate and phosphate. \\
\hline Inorganic phosphate $(\mathrm{P} i)$ & Central phosphorus atom surrounded by four oxygen atoms. \\
\hline Fructose-6-phosphate (F6P) & Ketose isomer of the aldose G6P \\
\hline
\end{tabular}


3. There are 10 chemical reactions involved in the glycolytic pathway. Table 2 describes what occurs in each of those reactions. Using the descriptions of each chemical reaction and the molecules identified above, assemble the glycolytic pathway by organizing the intermediates in the logical order of formation. Tape the intermediates on the easel sheet and connect the intermediates with arrows. Fill the table below with the names of the participant molecules.

Table 2. Chemical reactions in the glycolytic pathway.

\begin{tabular}{|c|c|c|c|c|c|}
\hline Step & Reactant & Description & Product & Enzyme & $\Delta \mathbf{G}$ \\
\hline 1 & & $\begin{array}{l}\text { A phosphoryl group is } \\
\text { transferred from ATP to the } \\
\text { C6-OH group of glucose }\end{array}$ & & & \\
\hline 2 & & $\begin{array}{l}\text { Isomerization; conversion to } \\
\text { fructose-6-phosphate }\end{array}$ & & & \\
\hline 3 & & $\begin{array}{l}\text { Phosphoryl group transfer } \\
\text { from ATP }\end{array}$ & & & \\
\hline 4 & & $\begin{array}{l}\text { Molecule splits to yield two, } \\
\text { three-carbon molecules }\end{array}$ & $\begin{array}{l}\text { Dihydroxyacetone } \\
\text { phosphate }+ \\
\text { glyceraldehyde 3- } \\
\text { phosphate }\end{array}$ & & \\
\hline 5 & & $\begin{array}{l}\text { Isomerization to } \\
\text { glyceraldehyde-3-phosphate }\end{array}$ & & & \\
\hline 6 & & $\begin{array}{l}\text { Two consecutive reactions: } 1 \text { ) } \\
\text { Oxidation of the intermediate } \\
\text { and reduction of } \mathrm{NAD}^{+} \text {, and } \\
\text { 2) addition of inorganic } \\
\text { phosphate (carbon } 1 \text { ) to form } \\
\text { a high energy intermediate. }\end{array}$ & & & \\
\hline 7 & & $\begin{array}{l}\text { Phosphoryl transfer from 1,3, } \\
\text { bisphosphoglycerate (carbon } \\
\text { 1) to ADP (substrate level } \\
\text { phosphorylation) }\end{array}$ & & & \\
\hline 8 & & $\begin{array}{l}\text { Isomerization reaction where } \\
\text { the phosphate group is } \\
\text { transferred from the } 3^{\text {rd }} \text { to the } \\
2^{\text {nd }} \text { carbon. }\end{array}$ & & & \\
\hline 9 & & $\begin{array}{l}\text { Dehydration reaction. As the } \\
\text { molecule of water is } \\
\text { removed, a new double bond } \\
\text { is formed. The resulting } \\
\text { molecule is a high energy } \\
\text { compound. }\end{array}$ & & & \\
\hline 10 & & $\begin{array}{l}\text { Transfer of the phosphoryl } \\
\text { group to ADP (substrate level } \\
\text { phosphorylation). The } \\
\text { resulting molecule is a three } \\
\text { carbon molecule partially } \\
\text { oxidized. }\end{array}$ & & & \\
\hline
\end{tabular}


4. Determine which enzyme is responsible for catalyzing each chemical reaction. Tape the name of each enzyme below each arrow in the pathway. Consider the following definitions:

Mutase: Catalyzes the transfer of a functional group from one position to another on a molecule.

Aldolase: Catalyzes an aldol cleavage reaction; in this case, the production of an aldose, a monosaccharide that contains only one aldehyde group per molecule $(-\mathrm{CH}=\mathrm{O})$.

Enolase: A type of lyase enzyme that catalyzes a reaction where a group is eliminated to form a double bond. In this pathway, the enolase forms a "high energy" intermediate.

Dehydrogenase: is an oxidoreductase enzyme. Catalyzes the removal of hydrogen from a substrate to an electron carrier.

5. Table 3 specifies the actual free energy change $(\Delta \mathrm{G})$ values $\left(\mathrm{kJ} \cdot \mathrm{mol}^{-1}\right)$ for each chemical reaction catalyzed by the specified enzyme in heart muscle (Voet et al. 2016). Underneath each enzyme (assembled pathway) write the specific $\Delta \mathrm{G}$ value. NOTE: The enzymes are not in order.

Table 3. Free energy change values for chemical reactions in heart muscle.

\begin{tabular}{|l|c|}
\hline Enzyme & $\Delta \mathrm{G}\left(\mathrm{kJ} \cdot \mathrm{mol}^{-1}\right)$ \\
\hline Pholase & -2.4 \\
\hline Hexokinase & -25.9 \\
\hline Phosphoglycerate mutase & -27.2 \\
\hline Triose phosphate isomerase & -0.6 \\
\hline $\begin{array}{l}\text { Glyceraldehyde -3-phosphate dehydrogenase and } \\
\text { Phosphoglycerate kinase }\end{array}$ & -1.0 \\
\hline Pyruvate kinase & -13.9 \\
\hline Aldolase & -5.9 \\
\hline Phosphoglucose isomerase & -1.4 \\
\hline
\end{tabular}

6. Get your puzzle checked by the instructor and answer the following questions:

a. Glycolysis is divided into two stages:

Stage I. This stage is also known as the preparatory or investment stage because two ATPs are used to phosphorylate glucose. The formation of glyceraldehyde-3-phosphate marks the end of this stage. Thus, stage I comprises reactions to 
Stage II. This stage is also known as the payoff or energy recovery stage where glyceraldehyde-3-phosphate is converted to pyruvate and some ATP is generated. Thus, stage II comprises reactions to

b. How many ATPs are consumed during the first stage (energy investment) of glycolysis?

c. How many ATPs are consumed during the second stage (energy recovery) of glycolysis?

d. How many ATPs are produced during the first stage of glycolysis?

e. How many ATPs are produced during the second state of glycolysis?

f. What is the net ATP yield of glycolysis?

g. Specify during which steps are ATPs produced.

h. Specify during which steps are high-energy intermediates produced and what are those high-energy intermediates.

i. Determine what reactions might be reversible and irreversible.

j. What is the overall outcome of glycolysis? List all the molecules that result from this process.

k. What reaction(s) could potentially be the rate-determining steps?

1. What reaction is the rate-determining step of glycolysis? In other words, what is the most important regulation point of glycolysis? Explain.

m. Is oxygen necessary for glycolysis?

n. What reactions are phosphorylations?

o. What reactions are oxidation/reduction reactions?

p. Glycogen breakdown in muscle cells results in the formation of glucose-1-phosphate that is isomerized to glucose6-phosphate. If the source of glucose is endogenous glycogen, determine the step where this product enters the pathway.

\title{
Summary of Glycolysis
}

\author{
Glucose $+2 \mathrm{NAD}^{+}+2 \mathrm{ADP}+2 \mathrm{P}_{\mathrm{i}} \rightarrow 2$ Pyruvate $+2 \mathrm{NADH}+2 \mathrm{H}^{+}+2 \mathrm{ATP}$
}

\section{Cited References}

Nelson DL, Cox MM. 2013. Lehninger. Principles of Biochemistry. $6^{\text {th }}$ Ed.. New York: Freeman

Voet D, Voet JG, Pratt CW. 2016. Fundamentals of Biochemistry. $5^{\text {th }}$ Ed., Wiley. 


\section{Materials}

- Printed, cut, and laminated (recommended) enzymes and structures

- 25 " x 30 " easel pad

- Worksheets (one package per student)

- Envelopes with structures and enzymes (per group)

- $\quad$ Adhesive tape (per group)

- $\quad$ Thin markers (per group)

\section{Notes for the Instructor}

The current exercise is suitable for a $15-30$ student classroom where participants are organized in 3-4 student groups. Its implementation is facilitated if the physical features of the classroom allow for group work, preferably if laboratory or large tables are available. Completion of this activity, including a quick review of the pathway by the instructor, can easily be completed in one and a half hours. Students are not allowed to use books, notes or the internet while completing this exercise. A short lecture follows this hands-on activity. The finished and revised pathways are displayed on the classroom walls for future reference.

This activity is a formative exercise and it is not graded for accuracy. Instead, points for class participation are granted. However, a formal assessment follows in the format of a quiz that students take during the following class meeting.
I highly recommend laminating the structures and names of the enzymes as these can be reused in the future. Students often ask if they can have access to the structures for practice. Thus, the student outline includes these materials.

\section{Cited References}

Nelson DL, Cox MM. 2013. Lehninger. Principles of Biochemistry. Sixth edition. New York: Freeman

Songer CJ, Mintzes JJ. 1994. Understanding cellular respiration: An analysis of conceptual changes in college Biology. Journal of Research in Science Teaching 31:6621-637.

Voet D, Voet JG, Pratt CW. 2016. Fundamentals of Biochemistry. Fifth edition. Wiley.

\footnotetext{
About the Author

Alma Rodriguez Estrada is Associate Professor of Biology at Aurora University. She teaches a variety of lower and upper-level courses for science, non-science majors and pre-nursing students.
} 
Appendix A: Enzymes

\begin{tabular}{|c|}
\hline Hexokinase (HK) \\
\hline $\begin{array}{c}\text { Phosphohexose isomerase } \\
\text { (PGI) }\end{array}$ \\
\hline Phosphofructokinase (PFK) \\
\hline Aldolase \\
\hline $\begin{array}{c}\text { Triose phosphate isomerase } \\
\text { (TIM) }\end{array}$ \\
\hline
\end{tabular}

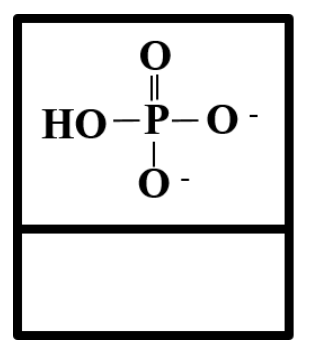

\begin{tabular}{|c|}
\hline $\begin{array}{c}\text { Glyceraldehyde 3-phosphate } \\
\text { dehydrogenase (GAPDH) } \\
\text { (PGK) }\end{array}$ \\
\hline $\begin{array}{c}\text { Phosphoglycerate kinase } \\
\text { (PGM) }\end{array}$ \\
\hline Enosphoglycerate mutase \\
\hline Pyruvate kinase (PK) \\
ATP ADP ATP ADP
\end{tabular}


Appendix B: Structures
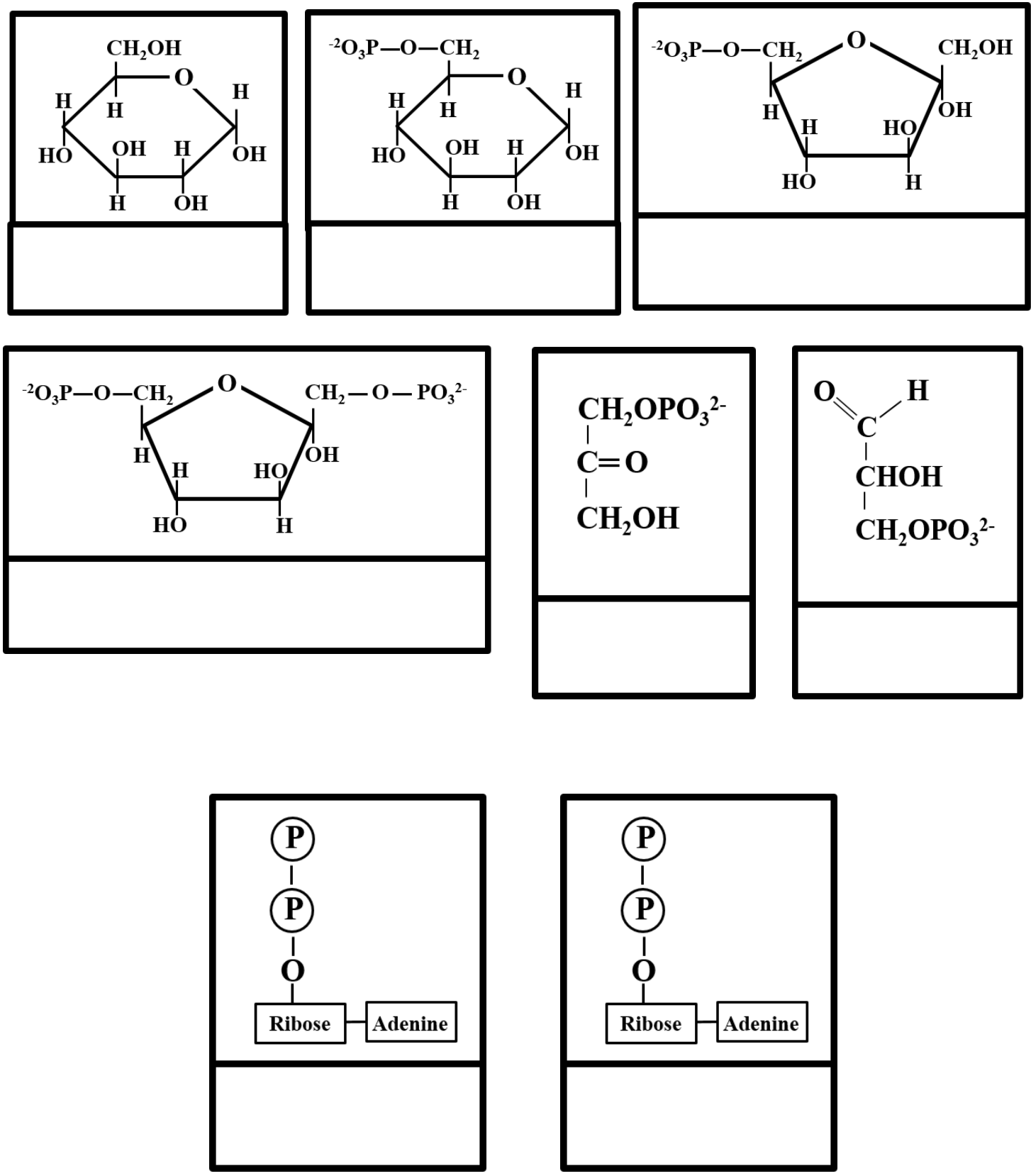

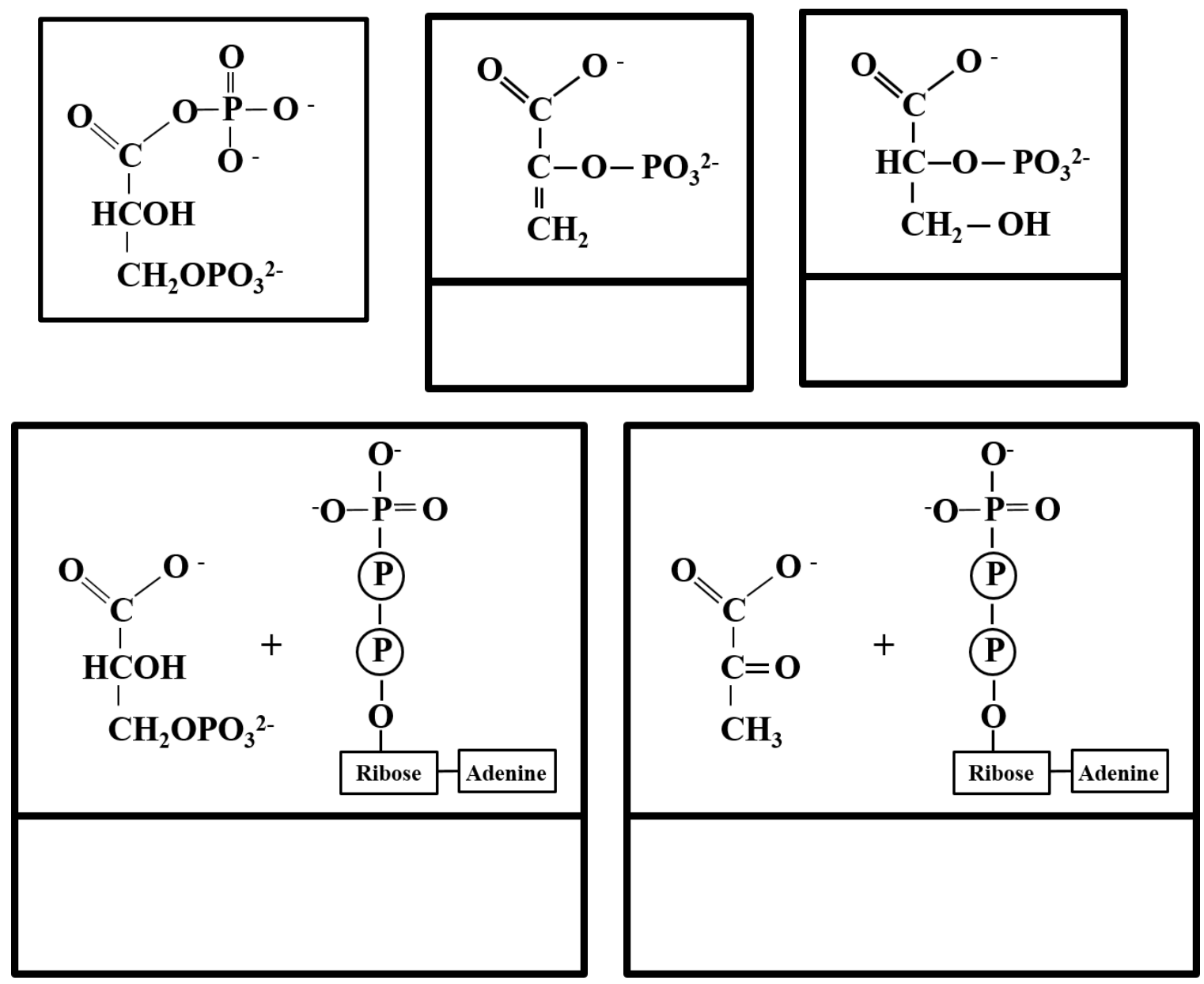


\section{Mission, Review Process \& Disclaimer}

The Association for Biology Laboratory Education (ABLE) was founded in 1979 to promote information exchange among university and college educators actively concerned with teaching biology in a laboratory setting. The focus of ABLE is to improve the undergraduate biology laboratory experience by promoting the development and dissemination of interesting, innovative, and reliable laboratory exercises. For more information about ABLE, please visit http://www.ableweb.org/.

Advances in Biology Laboratory Education is the peer-reviewed publication of the conference of the Association for Biology Laboratory Education. Published articles and extended abstracts are evaluated and selected by a committee prior to presentation at the conference, peer-reviewed by participants at the conference, and edited by members of the ABLE Editorial Board. Published abstracts are evaluated and selected by a committee prior to presentation at the conference.

\section{Citing This Article}

Rodriguez Estrada AE. 2020. The glycolysis puzzle: From glucose to pyruvate and everything in between. Article 51 In: McMahon K, editor. Advances in biology laboratory education. Volume 41. Publication of the 41st Conference of the Association for Biology Laboratory Education (ABLE). https://doi.org/10.37590/able.v41.art51

Compilation (C) 2020 by the Association for Biology Laboratory Education, ISBN 1-890444-17-0. All rights reserved. No part of this publication may be reproduced, stored in a retrieval system, or transmitted, in any form or by any means, electronic, mechanical, photocopying, recording, or otherwise, without the prior written permission of the copyright owner.

ABLE strongly encourages individuals to use the exercises in this volume in their teaching program. If this exercise is used solely at one's own institution with no intent for profit, it is excluded from the preceding copyright restriction, unless otherwise noted on the copyright notice of the individual chapter in this volume. Proper credit to this publication must be included in your laboratory outline for each use; a sample citation is given above. 